\title{
RESEARCH
}

\section{Fine Mapping of the Autosomal Dominant Juvenile Open Angle Glaucoma (GLCIA) Region and Evaluation of Candidate Genes}

\author{
Sara L.F. Sunden, ${ }^{1}$ Wallace L.M. Alward, ${ }^{2}$ Brian E. Nichols, ${ }^{2}$ \\ Tanya R. Rokhlina, ${ }^{1}$ Arne Nystuen, ${ }^{1}$ Edwin M. Stone, ${ }^{2}$ and \\ Val C. Sheffield ${ }^{1,3}$
}

Departments of ${ }^{1}$ Pediatrics and ${ }^{2}$ Opthalmology, The University of lowa College of Medicine, lowa City, lowa 52242

\begin{abstract}
Juvenile Open Angle Glaucoma (GLClA) is an autosomal optic neuropathy that has been localized previously to chromosome 1q. Here we report the fine mapping of the disease region using YACs and a high density of polymorphic microsatellite markers. This study utilized two large JOAG pedigrees genotyped at 36 loci from chromosome 1q21-q31 to refine the GLCIA locus to a $-3-\mathrm{cM}$ region flanked by YAC-derived microsatellite markers DIS3665 and DIS3664. The candidate genes LAMC1, NPR1, and CNR2 were excluded from the region by linkage. Four other genes, SELE, SELL, TXGPI, and APTILGl, were determined to lie within the critical region through YAC content and linkage mapping. The YAC-STS content map of the critical region provides the groundwork for the construction of a transcription map and the identification of the disease-causing gene.
\end{abstract}

Glaucoma is an optic neuropathy characterized by cupping of the optic nerve head with resultant visual field loss, usually in the presence of increased intraocular pressure. Primary open angle glaucoma (POAG) is the most common form of glaucoma with the age of onset generally over 40 (Leske 1983). The molecular mechanisms of POAG are unknown, and it is likely to be a genetically heterogeneous disease with a variety of biochemical causes. Autosomal dominant juvenile open angle glaucoma (JOAG) is a less common, early-onset form of the disease. Identification of the gene that causes JOAG may provide important clues to the biochemical mechanisms underlying the more common, late-onset form of the disease. The GLC1A locus responsible for JOAG originally was localized to chromosome 1q21-q31 by genetic linkage analysis of a single large pedigree (Sheffield et al. 1993). Linkage to chromosome 1 has been confirmed in other JOAG families, and the region has been narrowed by identification of recombination events in

${ }^{3}$ Corresponding author.

E-MAIL val-sheffield@uiowa.edu; FAX (319) 335-7588. those families (Richards et al. 1994; Wiggs et al. 1994; Morissette et al. 1995).

Following the original linkage study, we analyzed other members of the same family and an additional large family segregating the JOAG phenotype. Affected family members had normal-appearing trabecular meshworks, very high intraocular pressures, and presented with symptoms at an early age. The present study was designed to exploit the power of these large families, combined with yeast artificial chromosome (YAC)-sequence tagged site (STS) content mapping and targeted microsatellite development for narrowing the disease region. In addition, a highresolution genetic map of the region was developed, and several genes were evaluated as putative candidates for GLC1A.

\section{RESULTS}

Fine Mapping

Three dinucleotide-containing sequences were subcloned from YACs in the region via marker addition through subtraction (MATS; Chen et al. 1995). Two of these (D1S3665 and D1S3664) 


\section{FINE MAPPING OF JUVENILE OPEN ANGLE GLAUCOMA}

were informative in at least one JOAG family. The third, D1S3666, was monomorphic in the JOAG families in this study. A trinucleotide (ATA) repeat was found in the right-end subclone from YAC 74AA9. This short tandem repeat polymorphism (STRP) (D1S3663) was polymorphic within both JOAG families. The genetic map of 36 STRPs from 1q21-q31 is shown in Figure 1. Due to the density of polymorphic markers in the region, the exact genetic order of some STRPs could not be determined. Based on the genetic map, a YAC content map of the region between D1S431 and D1S480 was constructed to further determine marker order (Fig. 2). Additional STSs reported by the Whitehead Institute (1996) to be in the region and YAC-end sequences were also included in the STS content map. The order of STRPs determined by a combination of linkage and physical mapping is as follows (STRPs in parentheses could not be ordered relative to each other): D1S194, D1S196, (D1S431, D1S318), D1S397, D1S445, D1S443, AFM126yd8, D1S1569, (D1S3665，D1S3464), (D1S452, D1S210), D1S2851，D1S2815，(D1S1619, D1S1165), APT1LG1, 8AFM107YG1, TXGP1, D1S3664, AT3, D1S2634, (D1S2814, D1S1589),

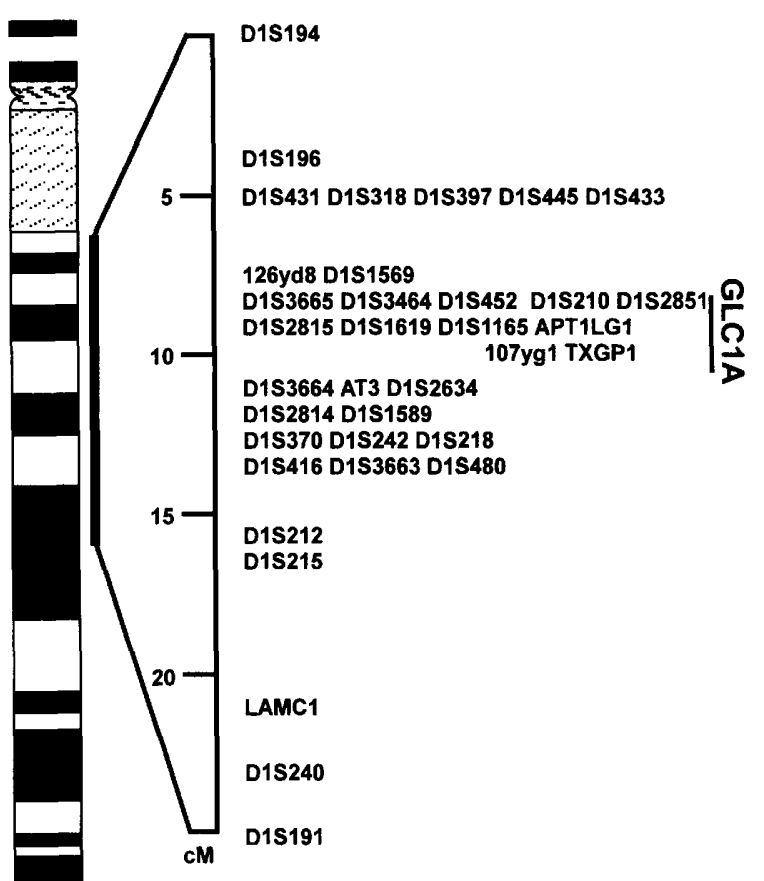

Figure 1 Linkage map of polymorphisms in the GLC1A region. Loci listed on the same line could not be ordered by linkage.
(D1S370, D1S242, D1S218), D1S416, (D1S3663, D1S480), D1S212, D1S215, LAMC1, D1S240, D1S191. An apparent gap in the YAC contig exists between D1S1165 and D1S2496. None of the seven YACs positive for D1S1165 amplifies D1S2496. Similarly, neither of the D1S2496containing YACs amplifies D1S1165. Radiation hybrid mapping of markers flanking the gap indicate the size is $-250 \mathrm{~kb}$. The region between D1S416 and D1S3663/D1S480 has been excluded from containing GLC1A and has not been characterized as extensively but contains another apparent gap. The physical size of the critical region was not determined empirically, but it is less than $5 \mathrm{Mb}$ based on the sizes of the YACs comprising a minimum tiling path, plus the maximum size of the apparent gap.

\section{Linkage Results}

Family B (Fig. 3) was genotyped with STRPs from the region to test for linkage to GLC1A. Family B was shown to be segregating the disease at GLC1A, with a maximum lod scores at $\theta=0$ of 6.27 (AT3), 6.12 (D1S445), and 5.92 (D1S210). Family A was the original family in which the GLC1A region was defined (Sheffield et al. 1993) with a maximum lod score at $\theta=0$ of 6.5 for D1S212. Analysis of the disease haplotype segregating in family B (Fig. 4) revealed that individual V-4 had a recombinant haplotype for STRPs D1S215, D1S240, and D1S191, indicating that GLC1A lies proximal to D1S215. Individual III-17 from family A further narrowed the interval on the distal side, having recombinant haplotypes for D1S3664 and other distal markers. Several individuals from family A exhibited a recombinant haplotype for STRPs proximal to D1S445. Family A member IV-10 was found to have a recombination event between 126yd8 and D1S3665, indicating the disease lies distal to 126yd8. Family A member IV-3 was also determined to be recombinant at $126 \mathrm{yd} 8$ by examination of the haplotypes inherited from each parent. Individual IV-8 of family B did not possess the affected allele for D1S3665 and other proximal STRPs. Thus, the disease must lie in the region defined by one recombinant-affected individual for D1S3665 and one recombinant-affected individual for D1S3664, a genetic distance of $2.5-3.5 \mathrm{cM}$.

\section{Mapping and Exclusion of Candidate Genes}

Two genes that map to the general region have 


\section{SUNDEN ET AL.}

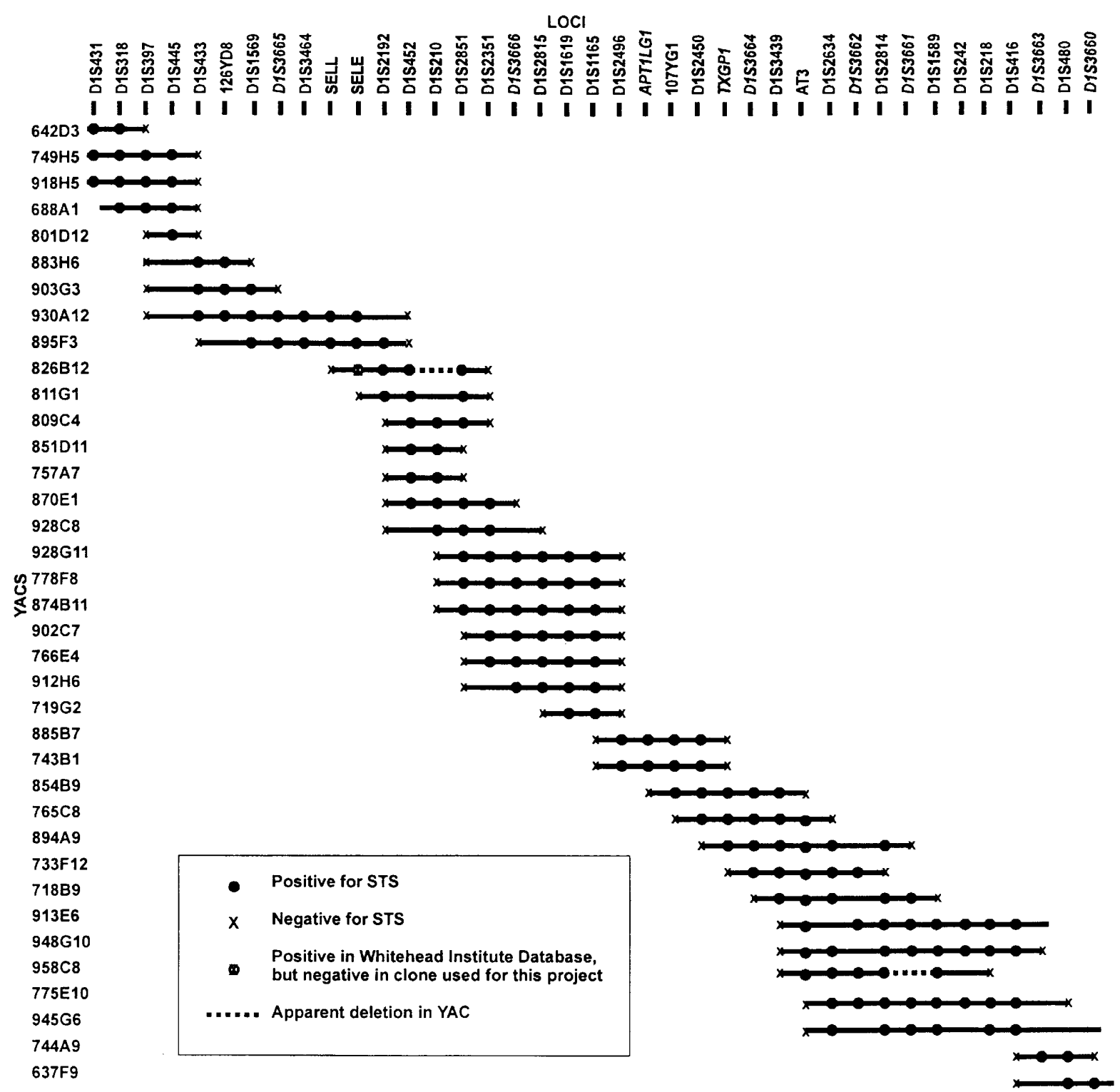

Figure 2 YAC contig of the GLC1A region. STSs listed in italics are newly reported and primer sequences are listed in Table 1.

been suggested as candidates for JOAG: laminin C1 (LAMC1) and atrionatriuretic peptide receptor A precursor (NPR1). Both genes contain polymorphisms that are informative within the families investigated in this study. The LAMC1 microsatellite (Watkins et al. 1993) showed recombination with the disease phenotype in four individuals in the JOAG families and has been mapped distal to the critical region by linkage (CHLC v8c7 integrated map, http:// www.chlc.org). An SSCP in the $3^{\prime}$ untranslated region (UTR) of NPR1 was uninformative for the majority of both families, but was recombinant in the affected members of family B, including VI-8, who is recombinant for the proximal portion of the interval. NPR1 has been mapped to 1q21-q22 (Lowe et al. 1990), supporting its placement proximal to GLC1A. A third gene, the peripheral cannabis receptor (CNR2; Munro et al. 1993), was evaluated as a candidate because of the reduction in intraocular pressure that cannabis causes in some patients with glaucoma. The gene was mapped to chromosome 1 by amplification of pooled DNA from the National Institute of General Medical Sciences (NIGMS) humanrodent single chromosome somatic cell hybrid 


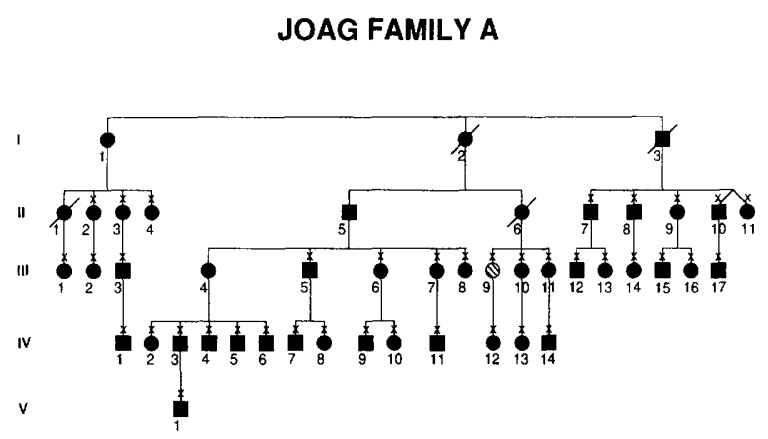

JOAG FAMILY B

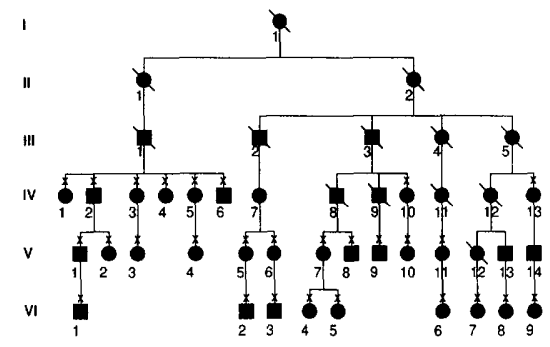

Figure 3 Pedigrees of three JOAG families used for this study. DNA samples were genotyped from individuals marked by " $x$." Only affected members are shown. Individual III-9 is phenotypically unaffected, although she possesses the complete disease haplotype and has a clearly affected daughter.

panel 2 as described previously (Sunden et al. 1996). A two-allele polymorphism was detected in the $3^{\prime}$ UTR of the gene by SSCP. Typing in Centre d'Etude du Polymorphisme Humain (CEPH) reference families mapped the gene by linkage to 1p34-p36, between liver alkaline phosphatase (ALPL) and alpha-L-1 fucosidase (FUCA1), excluding the gene from the GLC1A interval.

Three STSs identified by the Whitehead genome center that amplify from YACs within the region correspond to genes. STS D1S3363, was developed from selectin E (SELE) sequence (GenBank accession no. M24736). This gene encodes a cell-surface glycoprotein that mediates the adhesion of blood neutrophils (Bevilacqua et al. 1989). STS D1S3431, which maps to the same portion of the contig, amplifies a portion of selectin L (SELL; GenBank accession no. M25280), another member of the selectin family (Tedder et al. 1989). STS WI-7792 corresponds to the taxtranscriptionally activated glycoprotein 1 gene (TXGP1, GenBank accession no. D90224), a membrane protein that is a member of the tumor necrosis factor (TNF) gene family (Miura et al.

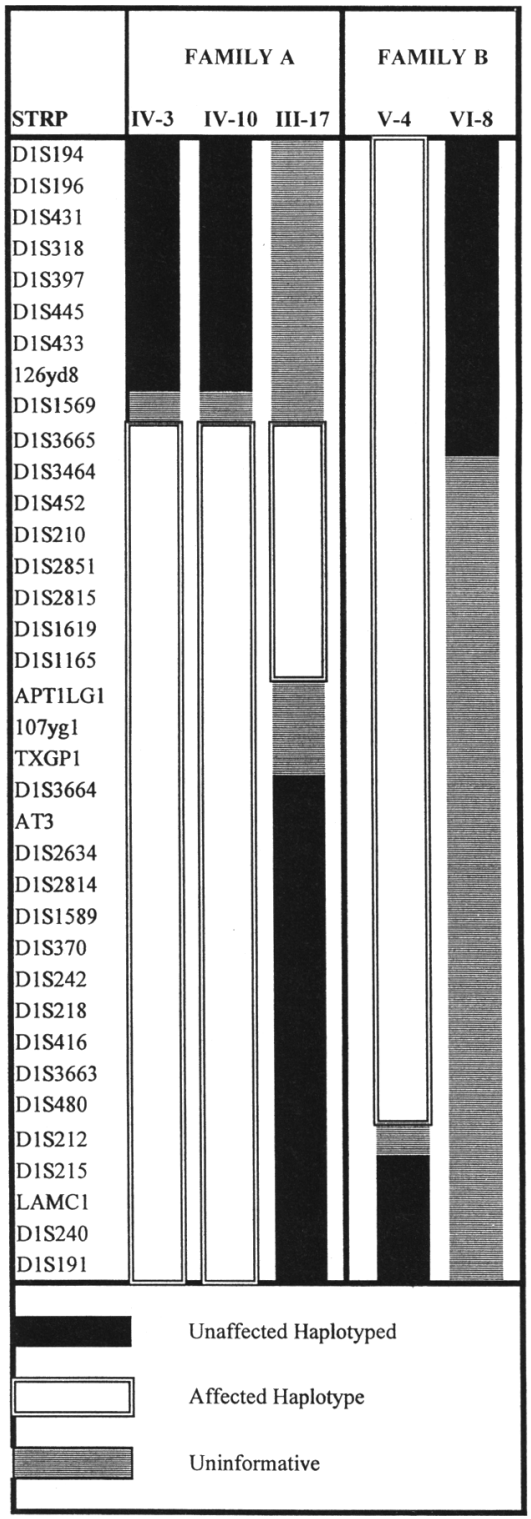

Figure 4 Haplotypes of selected individuals from JOAG families. Recombination events in family $B$ VI-8 and family A 111-17 define the current interval.

1991). The $3^{\prime}$ UTR of this gene contains a threeallele diucleotide repeat. The gene is completely linked in both families. Inheritance of the affected allele cannot be traced directly in family A member III-17, who defines the distal end of the region due to homozygosity of that person's affected parent for this locus. According to data from the YAC contig, TXGP1 lies inside the GLC1A critical region, just proximal to D1S3664.

One additional gene maps within the region by linkage and by YAC content. The apoptosis (APO-1) antigen ligand 1 (APT1LG1) is a small protein that is also a member of the TNF family 


\section{SUNDEN ET AL.}

and is important in apoptosis (Takahashi 1994). This gene contains a polymorphic dinucleotide repeat in the 3' UTR that is completely linked with the disease. The polymorphism for this gene has the same pattern of genotypes as TXPG1 in family A III-17. Consequently, whether this gene lies proximal or distal to the recombination breakpoints in this individual could not be determined. APT1LG1 maps to the distal portion of the GLC1A critical region on the YAC map, near D1S2496.

\section{DISCUSSION}

The identification of the gene causing JOAG has important implicatons for the understanding of this disorder and the more common adult POAG. At the time of the initial report of linkage of this disorder (Sheffield et al. 1993), only seven STRPs were mapped to the original $23-\mathrm{Cm}$ region. Since that time, genome-wide mapping efforts by several groups (Gyapay et al. 1994; Murray et al. 1994; Sheffield et al. 1995; Utah Marker Development Group 1995) have produced large collections of di-, tri- and tetranucleotide repeat markers distributed across the human genome. Between STRPs made public by those groups and targeted microsatellite development in our own laboratory, there are now 36 STRPs in the region, ten of which lie between the new flanking markers D1S3665 and D1S3664. The additional markers make it possible to narrow the GLC1A interval.

The density of markers surrounding JOAG is such that exact ordering by linkage analysis is difficult. Fine-mapping STRPs from the region required physical mapping using YACs. Screening the CEPH mega-YAC library with STRPs from the region identified 37 clones that comprise the YAC-STS content map. Mapping of STRPs within this framework made it possible to identify YACs from which to develop additional microsatellite markers. The contig also makes it possible to screen candidate genes for inclusion within the region. The apparent gap between D1S1165 and D1S2469/ATP1LG1 prevents one from excluding genes from the region based on nonamplification of YACs from the current contig. As expected, there is general ageement between the linkage and physical maps. For regions of highest marker density, a best order could not be obtained by linkage, but determination of marker order could be made using the physical map.
Large families make it possible to utilize only affected members in the analysis, thus avoiding the possibility of erroneous narrowing of the region based on genotypic data from a nonpenetrant individual. Once the region containing the gene is narrowed and evaluation of candidate genes for mutation analysis commences, it is beneficial to have more than one unrelated family to screen for the mutation. In this way, one is more likely to distinguish between a rare polymorphism and a true disease-causing mutation.

The refinement of the GLC1A critical region presented here is an important step for the identification of the disease-causing gene, either through positional cloning or through the positional candidate gene approach. The number of polymorphic markers accurately mapped to the region is now large enough to maximize informativity for screening new families with juvenile or later onset forms of glaucoma for linkage to GLC1A. The high density of STRPs is also useful for comparison of haplotypes between presumably unrelated families for the detection of an ancestral haplotype and further narrowing of the disease gene region. The families included in this study do not show notable similarities in the disease haplotype within the critical interval. Additional targeted marker development for the region is under way to further delineate the interval defined by recombination. STRPs at both ends of the current region are uninformative in the individuals with recombination events that define the interval, indicating that the region may be narrowed further.

Four genes are known to lie within the GLC1A region. SELE is a cell-surface glycoprotein expressed in leukocytes (Collins et al. 1991). SELL is highly homologous to mouse lymph node homing receptor core protein (mLHRc), and its expression in humans appears to be largely limited to lymphoid tissues (Siegelman and Weissman 1989). Both SELE and SELL are cell surface molecules involved in the regulation of inflammatory and immunological events at the interface of vessel wall and blood (Bevilacqua et al. 1989). TXGP-1 and APT1LG1 are TNF family proteins, also involved in immunological events. Because of the limited number of candidate genes that currently are identified to lie within the region, our focus is on narrowing the interval genetically and completing the physical contig of the region with YACs and smaller-insert cloning reagents. 
Table 1. Primer Sequences for Newly Reported STRPs, SSCPs, and STSs

\begin{tabular}{|c|c|c|c|c|c|}
\hline Locus & Source & $\begin{array}{l}\text { Size } \\
\text { (bp) }\end{array}$ & Forward primers sequence & Reverse primers sequence & Alleles \\
\hline D1S3660 & $\begin{array}{l}\text { Right end of } \\
\text { YAC } 637 F 9\end{array}$ & 123 & $\begin{array}{l}\text { GGAAATAAGTGGGAGAAA- } \\
\text { ACCC }\end{array}$ & ССТGСАTCCGACAAATGAC & 1 \\
\hline D1S3661 & $\begin{array}{l}\text { Right end of } \\
\text { YAC } 718 \mathrm{~B} 9\end{array}$ & 206 & $\begin{array}{l}\text { AGGCAACTCCTAGCACTA- } \\
\text { GCC }\end{array}$ & CAGGATCCCAAAGTGCTCAT & 1 \\
\hline D1S3662 & $\begin{array}{l}\text { Right end of } \\
\text { YAC 733F12 }\end{array}$ & 222 & $\begin{array}{l}\text { GGTTACCATCTGGCTCTCA- } \\
\text { TCC }\end{array}$ & TGCTCAGACACCCTGAAAAG & 1 \\
\hline D1S3663 & $\begin{array}{l}\text { Right end of } \\
\text { YAC 744A9 }\end{array}$ & 250 & $\begin{array}{l}\text { TGGTITGAAAAGAAAAGCA- } \\
\text { ATG }\end{array}$ & GGCCTTTGTTAACACTATCCAA & 4 \\
\hline D1S3664 & YAC 854B9 & 145 & AAGGCCTTAATATGGGTGGG & TGATITTTTCTGCAAAGATGC & 4 \\
\hline D1S3665 & YAC $895 F 3$ & 160 & $\begin{array}{l}\text { CAGTTITAAAGGACAGGTCA- } \\
\text { TGG }\end{array}$ & GCAGGTITAAACAGTCGACTCT & 8 \\
\hline D1S3666 & YAC $928 C 8$ & 230 & $\begin{array}{l}\text { AAGTCCTAAGATGCTAAGG- } \\
\text { GGC }\end{array}$ & GGGCAAAACATTGCСАCTAT & 1 \\
\hline APT1LG1 & 3' UTR & 217 & $\begin{array}{l}\text { ACTTCTAAATGCATATCCTGA- } \\
\text { GCC }\end{array}$ & ATCTTGACCAAATGCAACCC & 3 \\
\hline NPR1 & 3' UTR & 245 & GGCAAAGGCAAGGTTCGG & ССАTGCСАGTССССТСТСА & 2 \\
\hline TXGP1 & 3' UTR & 208 & CCAAGGCACTCACAGAATCA & TTGCAGAACATGGTCAATAACA & 3 \\
\hline CNR2 & 3' UTR & 150 & CTGACTCCTGGAAGACAGCC & GACTTCCCAAGAGAACAACCC & 2 \\
\hline
\end{tabular}

\section{METHODS}

\section{Patients}

The clinical features of the family that was the subject of the original linkage study (family A) have been described previously (Johnson et al. 1993). Twenty-one additional affected members have been evaluated. Twenty-eight affected members of a second family (family B) have also been ascertained and used for fine mapping of the region (Fig. 3). Clinical features of a related branch of this family were reported by Stokes (1940) and by Richards et al. (1994). Patients were classified as affected if they had intraocular pressures of greater than $30 \mathrm{~mm} \mathrm{Hg}$, if they had pressures above $21 \mathrm{~mm} \mathrm{Hg}$ with glaucomatous optic nerve cupping or visual field loss, or if they had intermediate pressures and at least one affected offspring. The clinicians who determined the affectation status were masked to the genotypic data. Unaffected pedigree members were not used for defining the region or to calculate LOD scores.

\section{Detection of Polymorphisms}

DNA was prepared from blood using a standard protocol (Grinsberg et al. 1989). Amplification of STRP from chromosome $1 \mathrm{q}$ were performed in $8.4-\mu \mathrm{l}$ reactions containing 10-40 ng DNA, 1.5 $\times$ Taq polymerase buffer (Boehringer Mannheim), $200 \mu \mathrm{M}$ each dCTP, dATP, dGTP, and dTTP, 1 pmole each primer, and 0.25 units Taq polymerase (Boehringer Mannheim). Samples were subjected to 35 amplification cycles of $94^{\circ} \mathrm{C}$ for $30 \mathrm{sec}, 55^{\circ} \mathrm{C}$ for $30 \mathrm{sec}$, and $72^{\circ} \mathrm{C}$ for $30 \mathrm{sec}$. STRP PCR products were electrophoresed on $6 \%$ denaturing polyacrylamide gels $(7.7 \mathrm{M}$ urea). Single-strand conformation polymorphisms (SSCP) were detected with room temperature electrophoresis in 6\% (49:1) nondenaturing arylamide gels containing $5 \%$ glycerol. Gels were stained with silver (Bassam et al. 1991; Sunden et al. 1996) and permanent records created by exposure of the gels to duplicating film (Typon APC film, Promega). STRPs developed and assigned to chromosome 1 by the Cooperative Human Linkage Center (CHLC) using a somatic cell hybrid panel (Sunden et al. 1996) were screened for linkage to the GLC1A region by comparing amplification patterns of pooled DNA from affected individuals with pooled DNA from their unaffected siblings as in Sheffield et al. (1994). STRPs that showed differential intensity of amplified alleles between pools were tested for linkage by genotyping individuals in the families.

\section{Identification, Preparation, and STS Content Mapping of YAC Clones}

YAC clones were selected in two ways. Approximately half the clones in the contig were identified from the CEPH YAC library via amplification of STRPs from the region between D1S218 and D1S196 using pooled DNA (Research Genetics). We also evaluated clones identified as positive by the Whitehead Institute's Human Genome Mapping Project (Whitehead Institute 1996). Individual clones were obtained (Research Genetics), and single colonies from each clone were selected for analysis after streaking on selective (URA-TRP) media. Total DNA was prepared from 5 -ml cultures for individual clones. All clones were tested by PCR amplification of STSs using the same conditions as used for genomic DNA except that only 5-10 ng total clone DNA was used per reaction. STSs with weak signals were amplified in the presence of Taq Extender (Strata- 


\section{SUNDEN ET AL.}

gene) to enhance amplification. PCR products were electrophoresed on polyacrylamide gels as described for genomic STRP analysis, except that PCR reactions were loaded in a staggered fashion to eliminate false positives from bleed-over between lanes. Each amplification was performed at least twice, independently, to verify results.

\section{Targeted Development of STRPs and STSs}

Ends of YACs were subcloned using circularization and inverse PCR following digestion of total clone DNA with HaeIII (Joslyn et al. 1991). PCR fragments containing YAC ends were purified and sequenced using fluorescent Dye Terminators (Applied Biosystems, Inc.). Primers were selected from the insert portion of the fragment with Primer 0.5 (Daly et al. 1991). Dinucleotide STRPs were selected from YACs using MATS (Chen et al. 1995) and sequenced using an ABI automated sequencer with Dye Primer chemistry. Primers flanking each microsatellite were then selected using Primer 0.5 (Daly et al. 1991). Primer sequences for newly developed STRPs, SSCPs, and STSs are listed in Table 1.

\section{Linkage Mapping}

A subset of STRPs (D1S431, D1S318, D1S433, 126yd88, D1S3464, D1S2851, D1S452, D1S1165, D1S210, D1S1619, AT3, ATA4E02, and D1S3663) were typed in 12-25 CEPH families. Genotypes were analyzed using CRI-MAP 2.4. STRPs were inserted one at a time into an initial framework map consisting of D1S318, D1S452, and D1S1589. Alternative locus orders were evaluated using the FLIPS routine. Double-recombinant individuals within the interval were identified with the CHROMPIC option and retyped for verification or correction. The resulting map was integrated with a map of CHLC and other published STRPs (Cooperative Human Linkage Center, unpubl.) to obtain a map of 36 STRPs in the region.

\section{ACKNOWLEDGMENTS}

The authors thank the family members for their enthusiastic participation in the study; C. Taylor, L. Streb, and A. McClain for excellent technical assistance; and D. Crouch, T. Johnson, and R. Ritch for assistance in identifying and evaluating family members. This work was supported by Public Health Service Research Grants EY10564, HG00457, and EY10539; Carver Foundation Charitable Trust, Muscatine IA; Glaucoma Foundation, NY; Foundation Fighting Blindness, Hunt Valley, MD; George Gund Foundation, Cleveland, $\mathrm{OH}_{\text {; }}$ Grousbeck Family Foundation, Boston, MA. E.M.S. is a Research to Prevent Blindness Dolly Green Scholar.

The publication costs of this article were defrayed in part by payment of page charges. This article must therefore be hereby marked "advertisement" in accordance with 18 USC section 1734 solely to indicate this fact.

\section{REFERENCES}

Bassam, B.J., G. Caetano-Anolles, and P.M. Gresshoff.
1991. Fast and sensitive silver staining of DNA in polyacrylamide gels. Anal. Biochem. 196: $80-83$.

Bevilacqua, M.P., S. Stengelin, M.A. Gimbrone, and B. Seed. 1989. Endothelial leukocyte adhesion molecule 1: An inducible receptor for neutrophils related to complement regulatory proteins and lectins. Science 243: $1160-1165$.

Chen, H., J.C. Pulido, an G.M. Duyk. 1995. MATS: A rapid and efficient method for the development of microsatellite markers from YACs. Genomics 25: 1-8.

Collins, T., A. Williams, G.I. Johnston, J. Kim, R. Eddy, T. Shows, M.A. Gimbrone, and M.P. Bevilacqua. 1991. Structure and chromosomal location of the gene for endothelial-leukocyte adhesion molecule 1. J. Biol. Chem. 266: 2466-2473.

Daly, M.J., S.E. Lincoln, and E.S. Lander. 1991. Primer unpublished software, Whitehead Institute/MIT Center for Genome Research. Available at http://www-genome.wi.mit.edu/ftp/pub/software/primer.0.5, and via anonymous ftp to ftp-genome.wi.mit.edu, directory/pub/software/primer.0.5.

Griffith, T.S., T. Brunner, S.M. Fletcher, D.R. Green, and T.A. Ferguson. 1995. Fas ligand-induced apoptosis as a mechanism of immune privilege. Science 270: 1189-1192.

Grimberg, J., S. Nawoschik, L. Belluscio, R. McKee, A. Turck, and A. Eisenberg. 1989. A simple and efficient non-organic procedure for the isolation of genomic DNA from blood. Nucleic Acids Res. 17: 8390.

Gyapay, G., J. Morissette, A. Vignal, C. Dib, C. Fizames, P. Millasseau, S. Marc, G. Bernardi, M. Lathrop, and J. Weissenbach. 1994. The 1993-94 Genethon human genetic linkage map. Nature Genet. 7: 246-339.

Johnson, A.T., A.V. Drack, A.E. Kwitek, R.L. Cannon, E.M. Stone, and W.L.M. Alward. 1993. Clinical features and linkage analysis of a family with autosomal dominant juvenile glaucoma. Ophthalmology 100: 524-529.

Joslyn, G., M. Carlson, A. Thliveris, H. Albertsen, L. Gelbert, W. Samowitz, J. Groden, J. Stevens, L. Spirio, M. Robertson, L. Sargeant, K. Krapcho, E. Wolff, R. Burt, J.P. Hughes, J. Warrington, J. McPherson, J. Wasmuth, D. Le Paslier, H. Abderrahim, D. Cohen, M. Leppert, and R. White. 1991. Identification of deletion mutations and three new genes at the familial polyposis locus. Cell 66: 601-613.

Leske, M.C. 1983. The epidemiology of open-angle glaucoma: A review. Am. J. Epidemiol. 118: 166-191.

Lowe, D.G., I. Klisak, R.S. Sparke, R. Mohandas, and D.V. Goeddel. 1990. Chromosomal distribution of three members of the human natriuretic peptide receptor/guanylyl cyclase gene family. Genomics 8: 304-312. 


\section{FINE MAPPING OF JUVENILE OPEN ANGLE GLAUCOMA}

Miura, S., K. Ohtani, N. Numata, M. Niki, K. Ohbo, Y. Ina, T. Gojobori, Y. Tanaka, H. Tozawa, and $\mathrm{M}$. Nakamura. 1991. Molecular cloning and characterization of a novel glycoprotein, gp34, that is specifically induced by the human T-cell leukemia virus type I transactivtor p40tax. Mol. Cell. Biol. 11: 1313-1325.

8 Morissette, J., G. Côte, J.-L. Anctil, M. Plante, M. Amyot, E. Héon, G.E. Trope, J. Weissenbach, and V. Raymond. 1995. A common gene for juvenile and adult-onset primary open-angle glaucomas confined on chromosome 1q. Am. J. Hum. Genet. 56: 1431-1442.

Munro, S., K.L. Thomas, and M. Abu-Shaar. 1993. Molecular characterization of peripheral receptor for cannabinoids. Nature 365: 61-65.

Murray, J.C., K.H. Buetow, J.L. Weber, S. Ludwigsen, T. Scherpbier-Heddema, F. Manion, J. Quillen, V.C. Sheffield, S. Sunden, G.M. Duyk, J. Weissenbach, G. Gyapay, C. Dib, J. Morrissette, G.M. Lathrop, A. Vignal, R. White, N. Matsunami, S. Gerken, R. Melis, H. Albertsen, R. Plaetke, S. Odelberg, D. Ward, J. Dausset, D. Cohen, and H. Cann. 1994. A comprehensive human linkage map with centimorgan density. Science 265: 2049-2054.

Nagata, S. and P. Golstein. 1995. The Fas death factor. Science 267: 1449-1456.

Richards, J.E., P.R. Lichter, M. Boehnke, J.L.A. Uro, D. Torrex, D. Wong, and A.T. Johnson. 1994. Mapping of a gene for autosomal dominant juvenile-onset open-angle glaucoma to chromosome 1q. Am. J. Hum. Genet. 54: $62-70$.

Sheffield, V.C., E.M. Stone, W.L.M. Alward, A.V. Drack, A.T. Johnson, L.M. Streb, and B.E. Nichols. 1993.

Genetic linkage of familial open angle glaucoma to chromosome 1q21-q31. Nature Genet. 4: 47-50.

Sheffield, V.C., R. Carmi, A. Kwitek-Black, T. Rokhlina, D. Nishimura, G.M. Duyk, K. Elbedour, S.L. Sunden, and E.M. Stone. 1994. Identification of a Bardet-Biedl syndrome locus on chromosome 3 and evaluation of an efficient approach to homozygosity mapping. Hum. Molecular Genet. 3: 1331-1335.

Siegelman, M.H. and I.L. Weissman. 1989. Human homologue of mouse lymph node homing receptor: Evolutionary conservation at tandem cell interaction domains. Proc. Natl. Acad. Sci. 86: 5562-5566.

Stokes, W.H. 1940. Hereditary primary glaucoma. Arch. Ophthalmol. 24: 885-909.

Sunden, S.L.F., T. Businga, J. Beck, A. McClain, J.M. Gastier, J.C. Pulido, C.H. Yandava, T. Brody, J. Ghazizadeh, J.L. Weber, G.M. Duyk, J.C. Murray, K.H. Buetow, and V.C. Sheffield. 1996. Chromosomal assignment of 2900 tri- and tetranucleotide markers using NIGMS cell panel \#2. Genomics 32: 15-20.

Takahashi, T., M. Tanaka, J. Inazawa, T. Abe, T. Suda, and S. Nagata. 1994. Human Fas ligand: Gene structure, chromosomal location and species specificity. Int. Immunol. 6: 1567-1574.

Tedder, T.F., C.M. Isaacs, T.J. Ernst, G.D. Demetri, D.A. Adler, and C.M. Disteche. 1989. Isolation and chromosomal localization of cDNAs encoding a novel human lymphocyte cell molecule, LAM-1. Homology with the mouse lymphocyte homing receptor and other human adhesion proteins. J. Exp. Med. 170: 123-133.

Utah Marker Development Group. 1995. A collection of ordered tetranucleotide-repeat markers from the human genome. Am. J. Hum. Genet. 57: 619-628.

Watkins, H.C., C.A. MacRae, L. Thierfelder, W.J. McKenna, C.E. Seidman, and J. Seidman. 1993. A dinucleotide repeat polymorphism in the human LAMB2 gene on chromosome 1q. Hum. Mol. Genet. 2:1084.

Whitehead Institute/MIT Center for Genome Research. (May 1996). Human Genetic Mapping Project, Data Release 10.

Wiggs, J.L., J.L. Haines, C. Paglinauan, A. Fine, C. Sporn, and D. Lou. 1994. Genetic linkage of autosomal dominant juvenile glaucoma to $1 \mathrm{q} 21-\mathrm{q} 31$ in three affected pedigrees. Genomics 21: 299-303.

Received June 10, 1996; accepted in revised form August 2, 1996. 


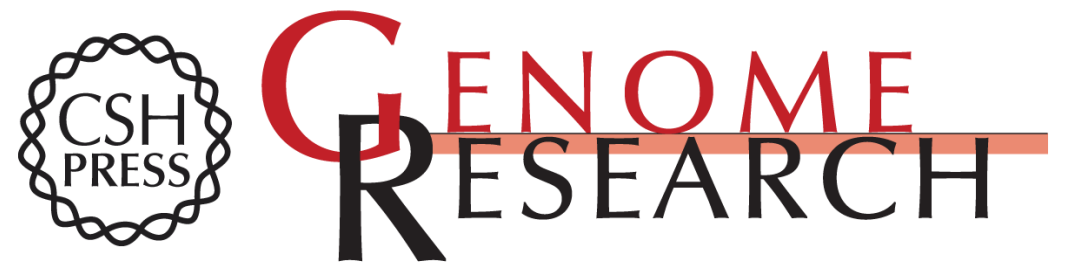

\section{Fine mapping of the autosomal dominant juvenile open angle glaucoma (GLC1A) region and evaluation of candidate genes.}

S L Sunden, W L Alward, B E Nichols, et al.

Genome Res. 1996 6: 862-869

Access the most recent version at doi:10.1101/gr.6.9.862

References This article cites 27 articles, 8 of which can be accessed free at:

http://genome.cshlp.org/content/6/9/862.full.html\#ref-list-1

\section{License}

Email Alerting Receive free email alerts when new articles cite this article - sign up in the box at the Service top right corner of the article or click here.

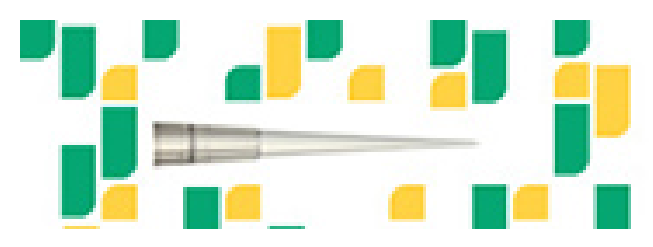

To subscribe to Genome Research go to: https://genome.cshlp.org/subscriptions 